\title{
Old pollution abatement: priority setting
}

\author{
J. Tylcer ${ }^{1}$, L. Zenaty ${ }^{2}$, J. Gruntorad ${ }^{3}$ \& R. Pavlik ${ }^{4}$ \\ ${ }^{1}$ AQD-envitest, Czech Republic \\ ${ }^{2}$ Private Consultant, Czech Republic \\ ${ }^{3}$ Ministry of Environment, Czech Republic \\ ${ }^{4}$ ProGeo consulting, Czech Republic
}

\begin{abstract}
For old soil and groundwater pollution from the past, a 'polluter-pays' principle is not so simple to apply. Generally, a large-scale involvement of public financial sources is inevitable. Experience has proved that an appropriate information base and prioritisation are important conditions for effective allocation of effort and money for these purposes.

Presently, a new national priority setting system is being tested in the Czech Republic. It sorts all polluted sites into several basic categories according to the statement specifying a character of the actual or potential pollution impact to public health, environment and/or to other interests. For each category, a corresponding principle of necessary or desirable action for mitigation of the risk issuing from the site pollution is explicitly defined. A basic qualitative statement characterizing a site pollution impact is preferentially based on results of its risk analysis. A simple scoring system is used to assess urgency for investigation of sites with lacking or insufficient data.

Keywords: soil and groundwater pollution, old pollution, pollution impact, remedial action, priority setting.
\end{abstract}

\section{Introduction}

Care of soil and groundwater quality is one of important sustainable development pre-conditions. As for new pollution, a 'polluter-pays' principle presents an appropriate and effective tool for protection enforcement.

But old pollution from the past represents a more complex problem, requiring a different approach. It applies especially for post-communist countries where all industrial enterprises were owned solely by the state for many decades. 
This is the case of the Czech Republic. Its long and respectable industrial tradition is reflected also in a large number of sites with soil and groundwater pollution from the past. Thus, after the collapse of the communist regime in 1989, a new political representation declared responsibility of the state for old environmental damage from the past.

The subsequent industry privatisation triggered an ambitious national program aimed on mitigation of old pollution. It is managed together by special departments of the Ministry of Finance and the Ministry of Environment. The programme is far from being perfect but it has been in operation now for more than 10 years and there is a hope that it will cover most of the really worst cases.

Another special programme is focused on rehabilitation of damage connected with large-scale opencast brown coal mining and with uranium underground acid leaching. Smaller programs were aimed to remediation of former Soviet army bases and remediation of some old municipal landfills. Separately, a clean-up of a few hundred petrol filling stations was carried out in the frame of their reconstruction after their take-over by new private operators.

At the end of 2005, the number of sites with finished remediation reached something over 250. Altogether, about 1 billion USD was spent for these purposes from public budgets. Presently, about 100 million USD is allocated for remediation yearly.

Further requirements for remediation of an old pollution load are estimated somewhere between 1,5-3 billion USD. The central register of polluted sites (http://sez.cenia.cz/mapmaker/sez/) presently holds nearly 10000 localities of different kinds and with a very different level of knowledge on them.

It is apparent that remediation of all pollution from the past will be a very long process with big financial demands.

Experience has proved that an appropriate information base and prioritisation are important conditions for effective allocation of effort and money. Inconsistent criteria for priority setting are generally regarded as one of the weakest points of the current national remediation program in the Czech Republic.

From the same beginning of the old pollution abatement effort, there were attempts to implement some kind of priority ranking system that would be based on assessment of data characterizing a site and its pollution. Not one from the tested systems found its way into daily practice. It is not a simple task to develop really useful, well-balanced and friendly-to-use system that could serve as a supporting toll for decision-making. All such systems tend to incline more or less to one of two extreme alternatives - sophisticated hazard ranking systems or, alternatively, very simple systems trying to sort all sites into few categories.

Complex expert systems are based on the classification of a large number of parameters of different kinds. They could be a good tool for priority ranking providing there is an appropriate amount of data for all sites. But unfortunately, it is not the case in practice. Such systems also require a high level of data formalization. Formalization inevitably leads to partial loss of original information. Users have problems with low transparency of such systems and 
with orientation in them and their protocols. It is difficult for users to keep track of the assessment process, to develop their own picture of a site. Most of these systems are inspired by the US EPA Superfund hazard ranking system (US EPA [2]).

Simple systems keep only a few items of original information on which a ranking statement is based. An assessment process is highly subjective; its quality depends on knowledge and experience of an assessor. A user has no choice but to rely on his judgment.

There is a general and understandable reluctance of practice to complex systems with low transparency. A functional priority ranking system must be as simple as possible. On the other side, crudely simple systems proved to have no significant practical value for management of a pollution abatement process.

With all systems, there is a problem of proper and adequate balancing of the weight attributed to various factors that can play a role. In addition, their importance can differ for various stakeholders of a pollution abatement process.

Especially misleading could be systems issuing to one list of polluted sites ordering them according to their priority ranking index (let us say from zero to 100, for example).

There are also difficulties with compatibility of ranking sites with different depth of knowledge on which their assessment is based. Some sites were thoroughly investigated while others are only suspected for contamination. In some countries, registers for suspected and polluted sites are developed and operated separately.

\section{Priority setting system - principles}

In reaction to previous experience, a new priority ranking system is being developed in the frame of the research project of the Czech ministry of Environment (Tylčer et al. [1]). Presently, it is tested in the pilot area. Its synopsis is demonstrated in Table 1.

It is more accurate to speak about the system for categorisation of polluted sites than about priority settings. Its design is based on risk analysis principles.

The system sorts all polluted sites to few basic categories according to the general character of a further action that is necessary or desirable to mitigate site pollution impacts. These categories are specified in the column 1 of Table 1. This column represents an exhaustive set of all action principles that can come into question.

Character of a further action is explicitly designated by an impact that issues (or could issue) from the site pollution. Column 2 of Table 1 represents a full set of possible statements characterizing site pollution impacts. These qualitative statements characterizing a site pollution impact are preferentially based on results of a site risk analysis.

The character of further action depends also on a site knowledge level on which actual decision-making is based. For many sites, no information on contamination is available at all, but a suspicion issuing from a site use history must be taken into account. The system structure enables the holding of pollution 
suspected sites as one of the registered categories. An investigation is the only logical further step for such sites where existing information is not enough to make a final decision. Thus, statements characterizing situations with insufficient information are also included in column 2.

A seriousness of a pollution impact and thus a priority of a further action are strictly determined by this succession of the site impact character: human health risks - environmental risks - risks to other interests.

Table 1: $\quad$ Priority setting system - site categorisation.

\begin{tabular}{|c|c|c|c|c|c|}
\hline \multicolumn{2}{|c|}{1} & 2 & 3 & 4 & 5 \\
\hline \multirow{2}{*}{\multicolumn{2}{|c|}{$\begin{array}{l}\text { Site category - character } \\
\text { of a further action }\end{array}$}} & Site situation statement - & \multicolumn{3}{|c|}{ Site action priority code } \\
\hline & & pollution impact character & \multicolumn{2}{|c|}{$\begin{array}{l}\text { Basic } \\
\text { site code }\end{array}$} & Priority order \\
\hline \multirow[t]{2}{*}{$\begin{array}{l}\text { mitigation } \\
\text { action } \\
\text { necessary }\end{array}$} & $\begin{array}{l}\text { action } \\
\text { required } \\
\text { urgently }\end{array}$ & $\begin{array}{l}\text { actual unacceptable human health } \\
\text { risk confirmed }\end{array}$ & $\begin{array}{c}\text { A } \\
\text { actual }\end{array}$ & 3 & \multirow{7}{*}{$\begin{array}{l}\text { Simple } \\
\text { scoring with } \\
\text { respect to: } \\
\text { - character } \\
\text { and level of } \\
\text { pollution } \\
\text { (confirmed } \\
\text { or } \\
\text { suspected), } \\
\text { - pollution } \\
\text { migration } \\
\text { conditions, } \\
\text { - character, } \\
\text { size and } \\
\text { importance } \\
\text { of } \\
\text { threatened } \\
\text { interests }\end{array}$} \\
\hline & $\begin{array}{l}\text { action } \\
\text { required }\end{array}$ & $\begin{array}{l}\text { one of these situations: } \\
\text { - exceeding of environmental } \\
\text { legislation limits confirmed or } \\
\text { - pollution prevents to use the site } \\
\text { according to the master plan or } \\
\text { - pollution spreading confirmed }\end{array}$ & $\begin{array}{c}\text { A } \\
\text { actual }\end{array}$ & 2 & \\
\hline \multicolumn{2}{|c|}{ mitigation action desirable } & $\begin{array}{l}\text { pollution confirmed, general } \\
\text { discrepancy with environmental or } \\
\text { other interests, but none from } \\
\text { situations specified above }\end{array}$ & $\begin{array}{c}\text { A } \\
\text { actual }\end{array}$ & 1 & \\
\hline \multirow[t]{2}{*}{$\begin{array}{l}\text { site pollution } \\
\text { investigation } \\
\text { required }\end{array}$} & \multirow{3}{*}{$\begin{array}{l}\text { a need of a } \\
\text { mitigation } \\
\text { action can } \\
\text { not be } \\
\text { excluded } \\
\text { presently }\end{array}$} & $\begin{array}{l}\text { suspicious site - no information on } \\
\text { a site pollution }\end{array}$ & $\begin{array}{c}\mathrm{P} \\
\text { potential }\end{array}$ & 4 & \\
\hline & & $\begin{array}{l}\text { pollution confirmed but not enough } \\
\text { information for its assessment }\end{array}$ & $\begin{array}{c}\mathrm{P} \\
\text { potential }\end{array}$ & 3 & \\
\hline $\begin{array}{l}\text { pollution } \\
\text { monitoring } \\
\text { required }\end{array}$ & & $\begin{array}{l}\text { pollution confirmed, no information } \\
\text { on its possible spreading with time; } \\
\text { final decision will depend on future } \\
\text { pollution development }\end{array}$ & $\begin{array}{c}\mathrm{P} \\
\text { potential }\end{array}$ & 2 & \\
\hline \multicolumn{2}{|c|}{$\begin{array}{l}\text { institutional } \\
\text { site-use control required }\end{array}$} & $\begin{array}{l}\text { possibility of unacceptable human } \\
\text { health risk in case of change to the } \\
\text { more sensitive site-use }\end{array}$ & $\begin{array}{c}\mathrm{P} \\
\text { potential }\end{array}$ & 1 & \\
\hline \multirow{3}{*}{\multicolumn{2}{|c|}{ no further action required }} & $\begin{array}{l}\text { confirmed pollution above } \\
\text { background values, but not } \\
\text { unacceptable, no restrictions for } \\
\text { multi-purpose site use }\end{array}$ & $\begin{array}{c}\mathrm{N} \\
\text { none }\end{array}$ & 2 & - \\
\hline & & $\begin{array}{l}\text { low pollution probability due to the } \\
\text { known site-use history }\end{array}$ & $\begin{array}{c}\mathrm{N} \\
\text { none }\end{array}$ & 1 & - \\
\hline & & $\begin{array}{l}\text { no pollution, confirmed by } \\
\text { sampling }\end{array}$ & $\begin{array}{c}\mathrm{N} \\
\text { none }\end{array}$ & 0 & - \\
\hline
\end{tabular}


The system also distinguishes an actual (A) or potential (P) impact character - see designations in the column 3 of Table 1.

Strictly speaking, sites with low pollution or without pollution (N-site category) might not be considered by the system for polluted or pollution suspected sites. Theoretically, this category could include most of the whole territory of the Republic. But it is supposed that polluted sites with finished remediation and sites excluded from suspicion on the base of investigation results could be those that fall into $\mathrm{N}$-category from higher priority ranks. It would not be wise to delete such localities from the register completely, especially with regards to managerial requirements of a brownfield exploitation support.

The proposed system assigns a two or three-font code to each polluted site (Site Action Priority Code - see columns 3, 4, 5 in Table 1).

A coding is easy to understand and to remember for people that will use the system in their work. In any case, Table 1 represents the full interpretation key.

Two first fonts of the code are principal. They characterize the site according to statements in columns 1 and 2 of Table 1 .

The subsequent third font of the site action priority code provides additional, more subtle priority ranking:

- the size of a human health risk is ranked with respect to number of threatened population (3 quantitative groups are distinguished),

- risk of further pollution spreading is ranked with respect to groundwater migration conditions (scoring of few pre-defined types of hydrogeological environments),

- sensitivity of pollution receptor environments is ranked by assigning simple scoring to various factors - e.g. land-use type, various nature protection areas and zones, groundwater and surface water usage etc).

It is an occasion here for emphasising and illustrating the system construction approach: a number of people threatened, for example, by polluted drinking water can not be the primary criterion for priority ranking. In such a case, an authority must act regardless of it's concerns for one farm or a large town. The general character and urgency of an action is the same, only its extent may differ.

For sites with lacking and insufficient data, a third font of the priority code estimates urgency for their investigation. Priority ranking is necessary here because of a great number of suspected and inadequately investigated sites. With respect to budget and other constrains, an investigation and subsequent reclassification of all of them within a short time is unrealistic. The attached simple scoring system automatically generates an investigation priority ranking. It is based on thoughtful analysis of more complex scoring systems and published generalizing studies of behaviour of pollution plumes (Dahlen et al. [3], Newell and Connor [4], Newell and McGuire [5], Mc Guire et al. [6], Mc $\mathrm{Nab}$ et al. [7], Teutsch et al. [8]). Estimation of a pollution character, migration conditions and sensitivity of possible receptors are taken into consideration as decisive risk elements for the ranking. 


\section{Site covering form}

The proposed priority categorisation system is supposed to become an integral element of the national register of polluted sites that is already in operation for many years.

So-called Site covering form was developed in the frame of the system proposal. It concentrates to one printable sheet all basic data characterizing the site, site conditions, its pollution and pollution receptors. The form also contains all information exploited as entry data for the site priority categorisation that runs automatically. The most of the form itself is also generated automatically for sites already stored in the register. For new sites, filling the Site covering form is their first entry into it.

Answers to simple questions and selection from the offered menu options are preferred methods of the Site covering form filling. A certain space is also given to condensed characteristics in short free text entries to prevent possible misunderstandings and information losses that are common in cases of high formalization.

A Site covering form is supposed to be readily available for decision makers and other involved parties (including politicians and public, for example). The form construction enables to its reader to develop his own conceptual picture of a site and recheck reasons for given site categorisation.

Construction of the Site covering form will enable also various selection operations and map presentations. Reporting requirements of the European Environmental Agency (EEA) were also taken into account.

\section{Results and discussion}

The proposed system is aimed on being really applicable as the supporting toll for decision-making and management of the old pollution abatement process on the national and regional levels.

With respect to previous experience, it was resigned from the same beginning on development of a system issuing to one list ordering all sites according to some integral hazard index.

The proposed system sorts all sites into a few basic categories according to the explicitly stipulated character of further action that may be required or desirable.

A general term "mitigation measure" is employed for any type of further action. Its definition itself is very important for understanding the principles of the system application for managerial purposes: a mitigation measure may be represented by any kind of measure leading to a risk reduction (a groundwater source de-contamination can be substituted by the provision of an alternative drinking water supply, for example). A remediation may not mean only decontamination, but also pollution containment.

A mitigation measure with the highest priority is necessary in cases when an unacceptable human health risk exists. 
A mitigation measure is also required when quantitative concentration limits stipulated by legislation are exceeded (for a relevant environmental compartment under relevant circumstances). Non-conformance with legislation is regarded always as an unacceptable situation. The same applies in the case of a continuation in pollution spreading. Nevertheless, an urgency of these situations is lower than in the case of an unacceptable human health risk.

The desirability of a mitigation measure applies for situations where there is a general consent in higher environmental quality requirements but it is not possible to surcharge a mitigation measure on the ground of unacceptable health risk or exceeding some quantitative criterion explicitly stipulated by legislation. For example, the same pollution should be regarded differently in a national park than in a busy city centre surroundings.

Specification of this category is very important and it is in accordance with the most modern approaches based on a long and large practical experience with pollution abatement management in Netherlands (for example Otte et al. [9], Veraart et al. [10], Versluijs and Bogte [11], Weytingh and Steenwinkel [12] and others). There is no urgency to remedy such a site in case of money limitations but it is worth considering when some occasion arises.

The proposed system also accommodates experience from practice that calls for treating both sites with proved pollution and suspected sites as two categories of one problem. Also, an actual or potential character of a site pollution impact is taken into account.

The system is presently being tested in the pilot area. After testing, it is supposed to become an integral element of the national register of polluted sites that is already in operation.

\section{References}

[1] Tylčer, J., Ženatý, L., Pavlík, R., Výzkum systémového př̀stupu $k$ výběru priorit řešeni lokalit starých ekologických zátěži. Závěrečná zpráva o řěseni projektu SM/4/93/05 v roce 2006, pro MŽP (Research No. $\mathrm{SM} / 4 / 93 / 05$ on a systemic approach to priority selection for old pollution sites, Final Report for the Czech Ministry of Environment), 2006.

[2] U.S. EPA, Office of Solid Waste and Emergency Response, The Hazard Ranking System Guidance Manual, Interim Final, Publication USEPA 9345.1-07, 1992.

[3] Dahlen, P. R., Henry, E. J., Johnson, P. C., Matsamura, M., Recognizing shortcomings of critical site characterization data: Insight from a statewide, multi-site, leaking underground storage tank (LUST) study. Proc. of Geological Society of America, 2003 Seattle Annual Meeting, Seattle, Washington, 2003.

[4] Newell, C. J., Connor, J.A., Characteristics of Dissolved Petroleum Hydrocarbon Plumes, Results from Four Studies, API Tech Transfer Bulletin, 8 pp., 1997.

[5] Newell, C. J., McGuire, T. M., Historical and Retrospective Survey of Monitored Natural Attenuation Line of Inquiry Supporting Monitored 
Natural Attenuation and Enhanced Passive Remediation of Chlorinated Solvents. Groundwater Services, Inc. booklet, 2003.

[6] Mc Guire, T. M., Newell, C. J., Looney, B. B., Vengelas, K. M., Sink, C. H., Historical analysis of MNA: a survey of 191 chlorinatd solvents sites and 45 solvent plumes. Remediation, winter 2004, Wiley Periodicals, 2004

[7] McNab, W. W., Jr., Rice, D. W., Tuckfield, C., Evaluating chlorinated hydrocarbon plume behavior using historical case population analyses, Bioremediation Journal, 4(4), 311-335, 2000.

[8] Teutsch G., Gratwohl P., Schiedik T., Literatstudie zum natürlichen Rückhalt/abbau von Schadstoffen im Grundwasser. Handbuk Altlasten und Grundwasserschadensfälle, Zentralen Fachdienst Wasser-BodenAbfahl-Altlasten bei der Landesanstalt für Umweltschutz BadenWüttenberg, Karlsruhe, 1997.

[9] Otte, P.F., Cleen de., M., Mesman, M., Derivation of Local Soil Quality Objectives: A Road Map. Proc. of Consoil 2005, Bordeaux, 2005.

[10] Veraart J. L., Hoogeveen N.Y., Westrik K.G., A Dutch perspective on Soil Management. Proc. of Consoil 2005, Bordeaux, 2005.

[11] Versluijs, C. V., Bogte, J. J., How does the systém of monitoring the soil remediation in the Netherlands work? Proc. of Consoil 2005, Bordeaux, 2005 .

[12] Weytingh, K., Steenwinkel, M.d., The Dutch remediation criteria working on a new approach to set priorities for remediation. Proc. of Consoil 2005, Bordeaux, 2005. 